\title{
Potential of Rooftop PV Systems on Weekly Peak Load Shaving in Saudi Arabia
}

\author{
Hani Albalawi \\ Department of Electrical and Computer Engineering, University of Tabuk, Tabuk, KSA \\ Email: halbala@ut.edu.sa
}

How to cite this paper: Albalawi, H. (2018) Potential of Rooftop PV Systems on Weekly Peak Load Shaving in Saudi Arabia. Smart Grid and Renewable Energy, 9, 33-41. https://doi.org/10.4236/sgre.2018.92003

Received: December 31, 2017

Accepted: February 11, 2018

Published: February 14, 2018

Copyright $\odot 2018$ by author and Scientific Research Publishing Inc. This work is licensed under the Creative Commons Attribution International License (CC BY 4.0).

http://creativecommons.org/licenses/by/4.0/ (c) () Open Access

\begin{abstract}
In recent years, high annual increasing load demand in Saudi Arabia has led to large investments in the construction of conventional power plants, which use oil or gas as the main fuel. The government is considering a large deployment of renewable energy for its 2030 vision plan. The Kingdom of Saudi Arabia is one of the best potential candidates for harvesting solar energy because of the country's geographical location, clear sky, and vast land area. A recent energy policy announced by the government involves harvesting solar photovoltaic (PV) energy to reduce the country's reliance on fossil fuel and greenhouse gas emissions. Using rooftop PV systems can help to shave the peak load and lead to a significant savings in the power sector through the reduction of annual installation of conventional power plants and standby generators. Employing solar PV at the end user level helps to reduce the overloading of transmission and distribution lines as well as decreases power losses. This paper will provide ratings for different rooftop PV systems that are being considered for installation for customers with various needs. The distribution of PV installation among the customers is as follows: $5 \%$ residential, $10 \%$ commercial, and $20 \%$ government. The effect of PV output power on weekly peak demand has been evaluated. The paper has also investigated the impact of the temperature on PV output power, especially during the summer. The PV power contribution is analyzed based on the assumption that weekly peak power production of solar PV coincides with weekly peak load demand. The PV model is implemented in Matlab to simulate and analyze the PV power.
\end{abstract}

\section{Keywords}

Rooftop Solar, PV Model, Peak Load Shaving, Temperature

\section{Introduction}

Saudi Arabia's electricity market uses a vertically integrated structure in which 
the Saudi Electricity Company (SEC) is the dominant provider in the industry [1]. As of the end of 2016, SEC owned more than $69 \mathrm{GW}$ of generation capacity. This capacity was divided over four regions as shown in Figure 1 [2]. There are other independent power producers (IPP) and independent water and power producers (IWPP) selling the electricity they produced to SEC [1]. In 2014, the fuel mix for electricity generation was based on the burning of diesel, crude oil, and heavy fuel oil. These sources accounted for $68 \%$ of the fuel consumed while all other power was generated through the burning of natural gas. Saudi Arabia is an oil producing country and most of its revenue comes from oil exports. With the growing demand of oil for power generation and transportation needs, estimates have shown that, by 2028, 8.3 million barrels will be needed to be produced per day to provide for the increased demand [3]. As a result, more oil will be burned domestically which will impact Saudi Arabia's economy and income. It is critical for the country to employ alternative energy sources to meet future demand and reduce oil consumption. One of Saudi Arabia's valuable renewable resources is its solar energy due to the country's geographical location and high annual irradiation values compared to other areas including European and other western countries.

In 2014, a total of 56.609 thousand metric tons of oil equivalent has been burnt by SEC. This fuel accounts for $68.8 \%$ of the total energy sent to the grid [4]. Saudi Arabia's electricity demand has been growing at a significant rate. The demand increased 7\% from 2013 to 2014 [1]. The residential and commercial sectors are the primary cause for the high annual growth in demand as the growth rates in these sectors from 2013 to 2014 were approximately $8 \%$ and $8.49 \%$, respectively [4]. The peak load demand in 2014 reached 56,547 MW in

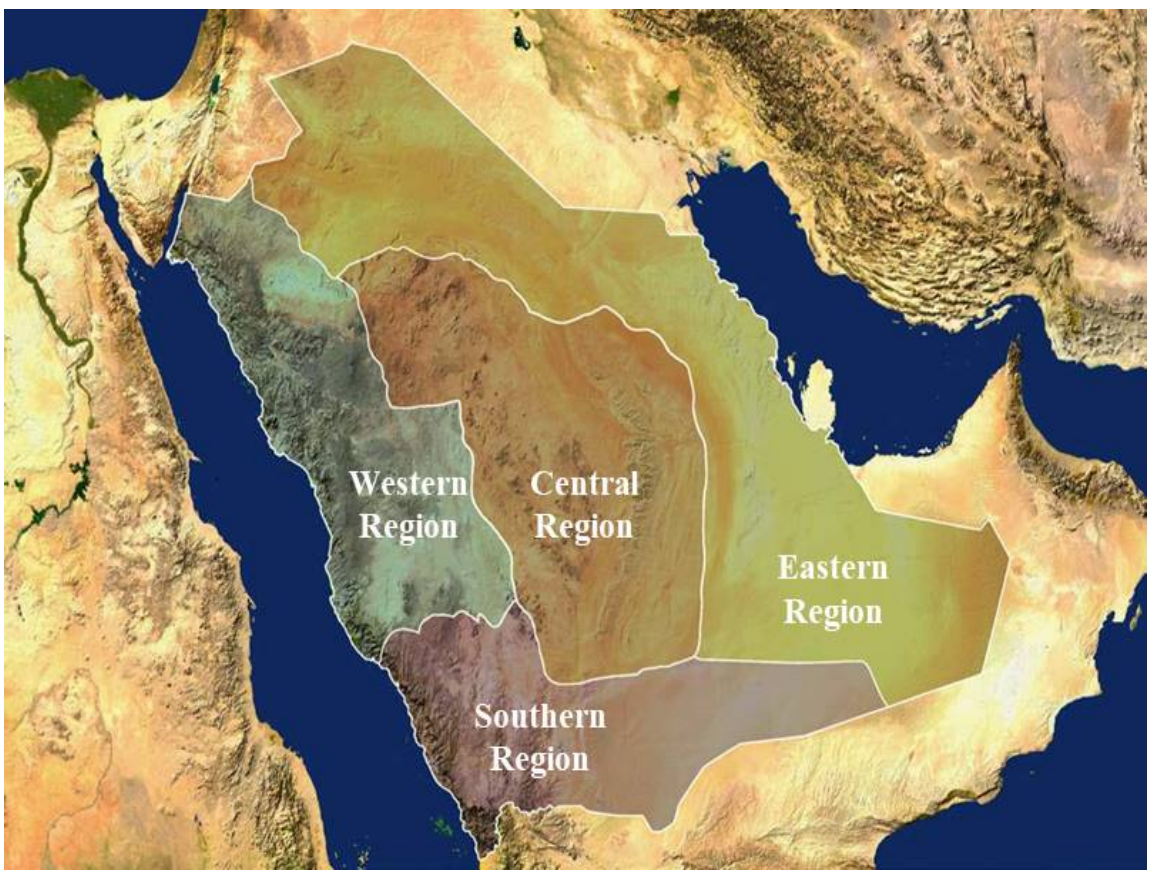

Figure 1. Electricity regions of SEC. 
August and was lowest in February at 32,622 MW [4]. The significant gap between the summer highs and winter lows in demand reduces the capacity factor of the power plants [4]. In 2015, the peak load demand was 62,260 MW, an increase of $10.2 \%$ compared to 2014 [3]. As a result, a huge investment in the power generation sector is needed to meet the high annual and ever-increasing demand. The peak load demand is estimated to reach approximately 71,940 MW in 2020 [1]. The total electrical energy sold in 2014 was 281,155 GWh while the total electrical energy delivered was $304,240 \mathrm{GWh}$ [1] [4]. The total electrical loss in the transmission and distribution system is approximately 23,085 GWh, an equivalent of $7.58 \%$ of the total electrical energy delivered. The overall efficiency of SEC power plants was $34 \%$ in 2014 , an efficiency level that is low and that can be attributed primarily due to the aging power plant infrastructure [4].

Residential, commercial, government, industrial, and other sectors consume $49.51 \%$, $15.61 \%, 10.93 \%, 18.76 \%$, and $5.19 \%$, respectively, of the total energy sold [4]. Using PV energy systems in residential, commercial, and governmental sectors can help to shave peak load demand and reduce the reliance on fossil fuel for electricity generation. This goal can be achieved through a government incentive program to encourage customers to invest in and install PV solar systems. This paper investigates rooftop PV systems in the residential, commercial, and governmental sectors to analyze the feasibility of using solar power in Saudi Arabia and to test the potential of the country in coping with increased future demand and weekly peak load reduction. The paper is organized as follows: Section 2 discusses load demand, Section 3 introduces solar energy potential in the country, Section 4 provides information about solar PV modules, and Section 5 discusses methodology and results.

\section{Load Demand in Saudi Arabia}

Load demand varies based on the season. Air conditioners are heavily used in the summer and heaters are rarely used in the winter. As a result, in 2015 the peak load in the summer was $62,260 \mathrm{MW}$ and the peak load in the winter was $34,274 \mathrm{MW}$, a reduction of $44.95 \%$ occurred [5].

Saudi Arabia faces an increase in electricity demand each year and has a yearly average growth rate of $7.2 \%$ [4]. The peak load has nearly tripled in the last 15 years and Figure 2 shows the dramatic increase of the peak load from 21,673 MW to 62,260 MW.

The primary factors that contribute to the increased demand are population growth and industrial development. According to K. A. CARE, the peak load is expected to reach $130 \mathrm{GW}$ by 2032 [3]. As a result, more generation is needed each year to meet future peak load demand.

In Table 1, the weekly peak load profile of the four main regions varies dramatically throughout 2015 [5]. The central, eastern, western, and southern regions contribute a maximum weekly peak load of $32.12 \%, 30.74 \%, 28.89 \%$, and $8.25 \%$, respectively. Table 1 also shows the maximum, minimum, and average 


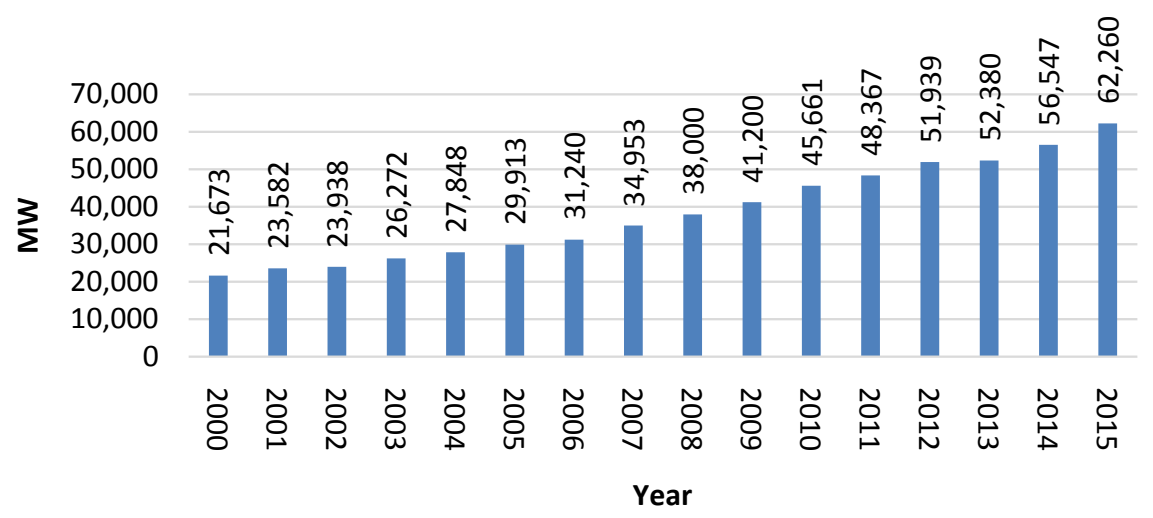

Figure 2. Annual increase in peak load demand, 2000-2015 [2] [4].

Table 1. Weekly peal load profile.

\begin{tabular}{cccccc}
\hline \multirow{2}{*}{$\begin{array}{c}\text { Weekly } \\
\text { Peak }\end{array}$} & $\begin{array}{c}\text { Central } \\
(\mathrm{MW})\end{array}$ & $\begin{array}{c}\text { Eastern } \\
(\mathrm{MW})\end{array}$ & $\begin{array}{c}\text { Western } \\
(\mathrm{MW})\end{array}$ & $\begin{array}{c}\text { Southern } \\
(\mathrm{MW})\end{array}$ & $\begin{array}{c}\text { Total } \\
(\mathrm{MW})\end{array}$ \\
\cline { 2 - 6 } & 19,999 & 19,135 & 17,991 & 5135 & 62,260 \\
Maximum & 8751 & 12,432 & 8408 & 3364 & 34,274 \\
Minimum & 13,764 & 15,634 & 13,179 & 4226 & 46,803 \\
Average & $32.12 \%$ & $30.74 \%$ & $28.89 \%$ & $8.25 \%$ & $100 \%$ \\
$\begin{array}{c}\text { Contribution by } \\
\text { region }\end{array}$ & & & & & \\
\hline
\end{tabular}

contribution of weekly peak load presented in the load profile in Figure 3. The southern region has a large number of residential and governmental customers, as shown in Table 2, yet this region only contributes an average of $8.25 \%$ of peak load demand. In this region, air conditioners are not heavily used due to the relatively cooler summers and few industrial customers compared to other regions [5] [6]. The daily peak load occurs during the middle of the day when temperatures are often the highest as shown by Rehman et al. [7]. During this time, daily peak load coincides with high solar irradiation.

\section{Solar Irradiation in Saudi Arabia}

Despite the fact that Saudi Arabia has large oil and natural gas reserves that can be extracted with minimal costs, the Saudi government is working to reach 9.5 GW of renewable energy sources by 2030 [8]. On average, Saudi Arabia's solar global radiation is more than $2000 \mathrm{kwh} / \mathrm{m}^{2} / \mathrm{yr}$ according to Rehman et al. [9]. Rehman et al. also studied global horizontal irradiation (GHI) on a horizontal surface in 41 locations throughout the country and found that a minimum of 1.64 MWh $/ \mathrm{m}^{2} / \mathrm{yr}$ and a maximum of $2.56 \mathrm{MWh} / \mathrm{m}^{2} / \mathrm{yr}$ of GHI were seen in Tabuk and Bisha, respectively. The average daily solar irradiation for Saudi Arabia was $4.05 \mathrm{kwh} / \mathrm{m}^{2} /$ day in January and $7.09 \mathrm{kwh} / \mathrm{m}^{2} /$ day in June [9]. In 1995, NASA worked with King Abdulaziz City for Science and Technology (KACST) 


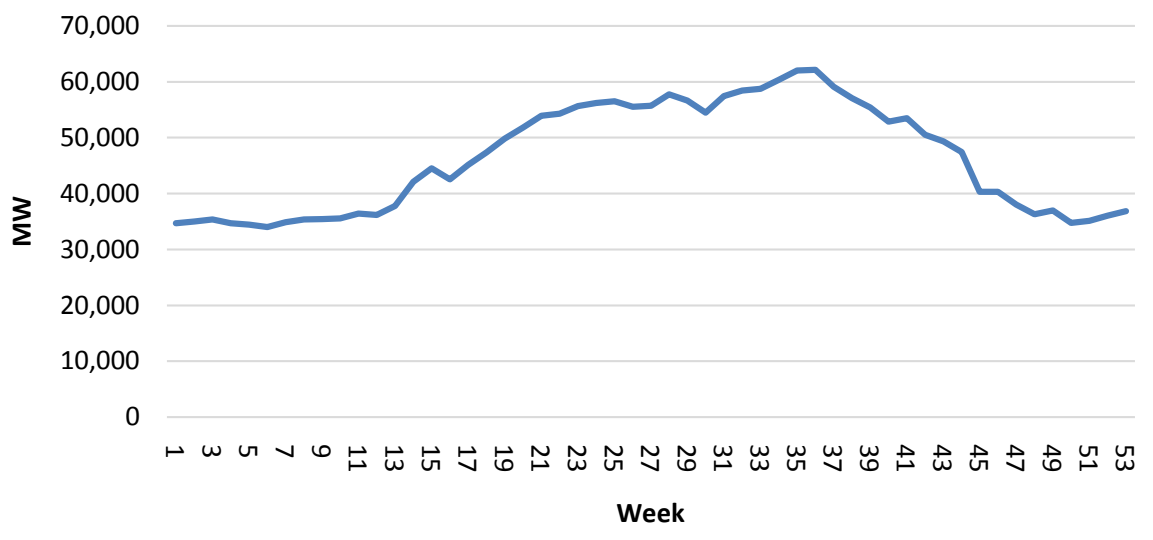

Figure 3. Weekly peak load demand in 2015 [5].

Table 2. Number of customers.

\begin{tabular}{cccccc}
\hline \multirow{2}{*}{ Customer type } & \multicolumn{5}{c}{ Region } \\
\cline { 2 - 6 } & Central & Eastern & Western & Southern & Total \\
\hline Residential & $2,007,566$ & $1,134,062$ & $2,374,802$ & 917,465 & $6,433,895$ \\
Commercial & 499,985 & 255,399 & 419,422 & 142,584 & $1,317,390$ \\
Government & 85,682 & 36,124 & 76,039 & 54,800 & 252,645 \\
Industrial & 3347 & 2557 & 3139 & 388 & 9431 \\
Other & 48,156 & 27,276 & 19,764 & 3982 & 99,178 \\
Total by region & $2,644,736$ & $1,455,418$ & $2,893,166$ & $1,119,219$ & $8,112,539$ \\
\hline
\end{tabular}

and established 12 remote sensing stations to record solar radiation and temperature throughout the country [10]. Measurements were taken every 5 minutes from January 1998 to December 2002. These data were used in this paper to generate PV output power as presented in [10]. Figure 4 shows the daily average $\mathrm{kWh}$ from January to December recorded by all stations in 2002. The maximum recorded solar irradiation was $7.92 \mathrm{kWh} / \mathrm{m}^{2}$ in June, while the lowest solar irradiation was $4.03 \mathrm{kWh} / \mathrm{m}^{2}$ in December. Since temperature impacts solar module efficiency, Figure 4 also presents the average temperature range.

More recent meteorological data were reported by K. A. CARE weather stations [11]. The data analyzed GHI, Diffuse Horizontal Irradiance (DHI), and Direct Normal Irradiance (DNI) in 30 stations throughout the country [11]. The average daily total GHI varied from $5700 \mathrm{kWh} / \mathrm{m}^{2}$ to $6700 \mathrm{kWh} / \mathrm{m}^{2}$ and the maximum daily total GHI recorded by the stations ranged from a minimum of $7720 \mathrm{kWh} / \mathrm{m}^{2}$ to a maximum of $8864 \mathrm{kWh} / \mathrm{m}^{2}$ [11]. The K.A.CARE meteorological stations recorded the ambient temperature at all 30 locations since temperature has a significant impact on PV module efficiency based on a study review presented in [12]. The average annual temperature ranged from a minimum of $23.2^{\circ} \mathrm{C}$ to a maximum of $30.7^{\circ} \mathrm{C}$ while the maximum daily average temperature recorded was $4^{\circ} \mathrm{C}$ at Hafar Al Batin [11]. 


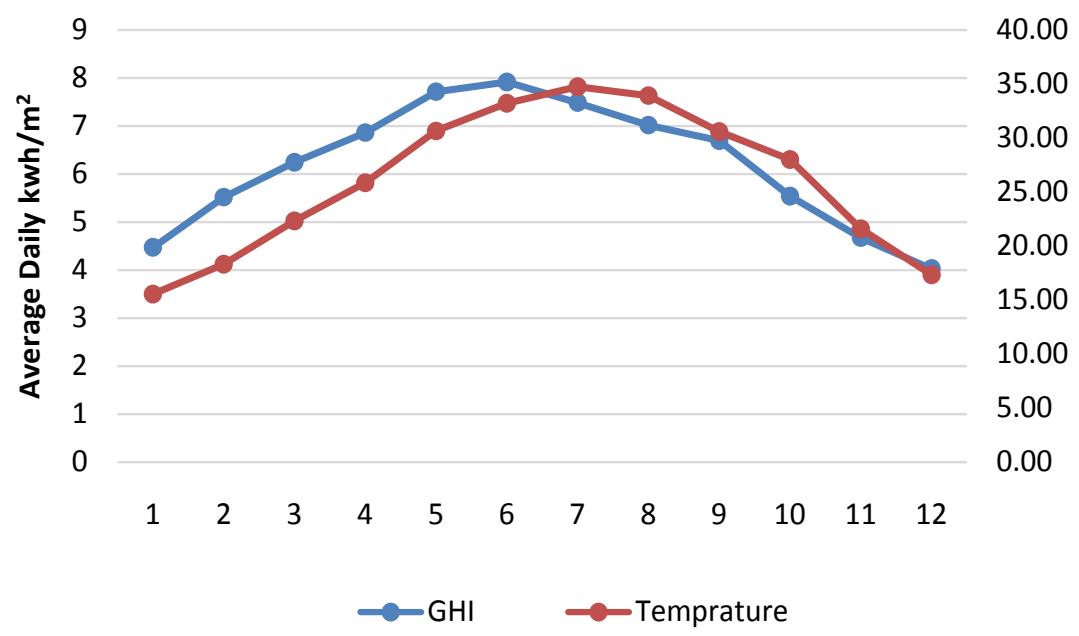

Figure 4. Average daily irradiation and temperature per month at all stations.

\section{Modeling of a PV Module}

In this research paper, a simplified model of the PV module was used [13]. The power output of the PV module is affected by irradiance and ambient temperature [12] [13]. For a solar PV module, the output power can be expressed in the following equation [12] [13]:

$$
P_{\mathrm{pv}}=\eta_{\mathrm{pv}} A_{\mathrm{pv}} I_{r}
$$

where, $\eta_{p v}, A_{p v}$ and $I_{r}$ are the power conversion efficiency of the PV module, surface area of PV panels in $\mathrm{m}^{2}$, and solar irradiance in $\mathrm{W} / \mathrm{m}^{2}$, respectively. The PV module efficiency is affected by temperature and the module's efficiency can be found using a reference module efficiency, $\eta_{r}$, given by the manufacturer at STC. Hence, the following equation is used [12]:

$$
\eta_{\mathrm{pv}}=\eta_{r} \times\left[1-\beta \times\left(T_{C}-T_{r}\right)\right]
$$

where, $T_{r}$ is the reference temperature at STC which is $25^{\circ} \mathrm{C}, \beta$ is the efficiency temperature coefficient of the PV module, and $T_{C}$ is the cell temperature. Cell temperature can be calculated using the equation below [12]:

$$
T_{C}=T_{a}+\left[\frac{(\mathrm{NOCT}-20)}{800} \times I_{r}\right]
$$

where NOCT is the normal operating cell temperature under an irradiance of $800 \mathrm{~W} / \mathrm{m}^{2}$, a temperature of $20^{\circ} \mathrm{C}$, and wind speed of $1 \mathrm{~m} / \mathrm{s}$.

By considering a DC-to-AC derating factor, $\gamma$, equal to 0.86 (95\% inverter efficiency, $5 \%$ losses due to dust accumulation, $3 \%$ wire losses, and $1 \%$ mismatch losses) without including temperature since it is used in the PV model, the following $\mathrm{AC}$ power output equation is used:

$$
P_{\mathrm{AC}}=\gamma \times P_{\mathrm{pv}} .
$$

The PV module used is a polycrystalline solar module manufactured by Trina Company (TSM-250 PC/PA05A). Table 3 shows the PV module data used in the simulation. The data are taken from the module data sheet at STC [14]. 
Table 3. PV model data [14].

\begin{tabular}{ccccc}
\hline $\begin{array}{c}\text { Maximum } \\
\text { Power }\end{array}$ & Module Area & $\begin{array}{c}\text { Module } \\
\text { Efficiency }\end{array}$ & $\boldsymbol{\beta}$ & NOCT \\
\hline $250 \mathrm{~W}$ & $1.553 \mathrm{~m}^{2}$ & $15.9 \%$ & $-0.41 \% / K$ & $46^{\circ} \mathrm{C} \pm 2{ }^{\circ} \mathrm{C}$ \\
\hline
\end{tabular}

\section{Analysis and Results}

In this paper, the effect of rooftop solar systems on the weekly peak load profile is investigated. The study is based on the assumption that weekly peak load coincides with weekly peak power of solar production. Three main sectors with different PV ratings were considered to have rooftop solar systems, which consisted of $5 \%$ of residential customers each having $5 \mathrm{KW}, 10 \%$ of commercial customers each having $50 \mathrm{KW}$, and $20 \%$ of governmental customers each having $50 \mathrm{KW}$. The distribution resulted in 503,963 customers using rooftop PV systems (321,693 residential customers, 131,740 commercial customers, and 50,529 governmental customers). The number of customers who used a PV system account for $6.2 \%$ of the total customers in the country. The distribution of customers who used rooftop solar systems was based on the contribution of each region to weekly peak demand. Table 4 shows the number of customers in each region for all sectors and the total number of customers in each region.

Figure 5 illustrates the output power of the PV system in each region. The highest PV penetration occurred in the western area with an average of $1728 \mathrm{MW}$ and a maximum of 1904.7 MW, which occurred in week 18 as seen in Figure 5. Figure 5 also shows that the highest PV power produced in all regions was 5824.8 MW in Week 15 while the minimum PV production was $4684.5 \mathrm{MW}$ in Week 51. Using the assumption of the simulation, the maximum rooftop PV system power represents $61.31 \%$ of the country's renewable target energy for its 2030 vision, $9.5 \mathrm{GW}$.

Figure 6 shows the weekly peak load shaving due to the PV penetration. The figure shows a significant reduction in the weekly peak load with an average reduction of $11.73 \%$. The highest weekly peak shaving occurred in Week 10 with a drop of $16.17 \%$ while the lowest shaving occurred in Week 35 with a reduction of $8.65 \%$. Figure 6 shows that the winter season has a higher weekly peak load reduction compared to the summer, which can be attributed to the impact of hot weather during the summer on PV output power. Hence, the efficiency of the PV system is always higher in the winter. The rooftop solar system succeeded in reducing the maximum peak load for 2015, starting in Week 36, from 62,260 MW to $56,824 \mathrm{MW}$, a decrease of $8.73 \%$.

\section{Conclusion}

The paper examined the potential of rooftop solar systems to allow weekly peak load shaving using different ratings of PV systems for three customer categories. Since only $6.2 \%$ of all customers use rooftop PV systems, a significant result was achieved. The maximum PV power produced is $5824.8 \mathrm{MW}$ using the assumption 
Table 4. Distribution of number of customer among all regions.

\begin{tabular}{cccccc}
\hline \multirow{2}{*}{$\begin{array}{c}\text { Customer } \\
\text { type }\end{array}$} & Central & Eastern & Western & Southern & Total by sector \\
\cline { 2 - 5 } Residential & 96,508 & 96,508 & 96,508 & 32,169 & 321,693 \\
& $\mathbf{3 0 \%}$ & $\mathbf{3 0 \%}$ & $\mathbf{3 0 \%}$ & $\mathbf{1 0 \%}$ & 131,740 \\
Commercial & 39,522 & 39,522 & 39,522 & 13,174 & $\mathbf{1 0 \%}$ \\
& $\mathbf{3 0 \%}$ & $\mathbf{3 0 \%}$ & $\mathbf{3 0 \%}$ & 5053 & 50,529 \\
Governmental & 15,159 & 15,159 & 15,159 & $\mathbf{3 0 \%}$ & 50,396 \\
\hline
\end{tabular}

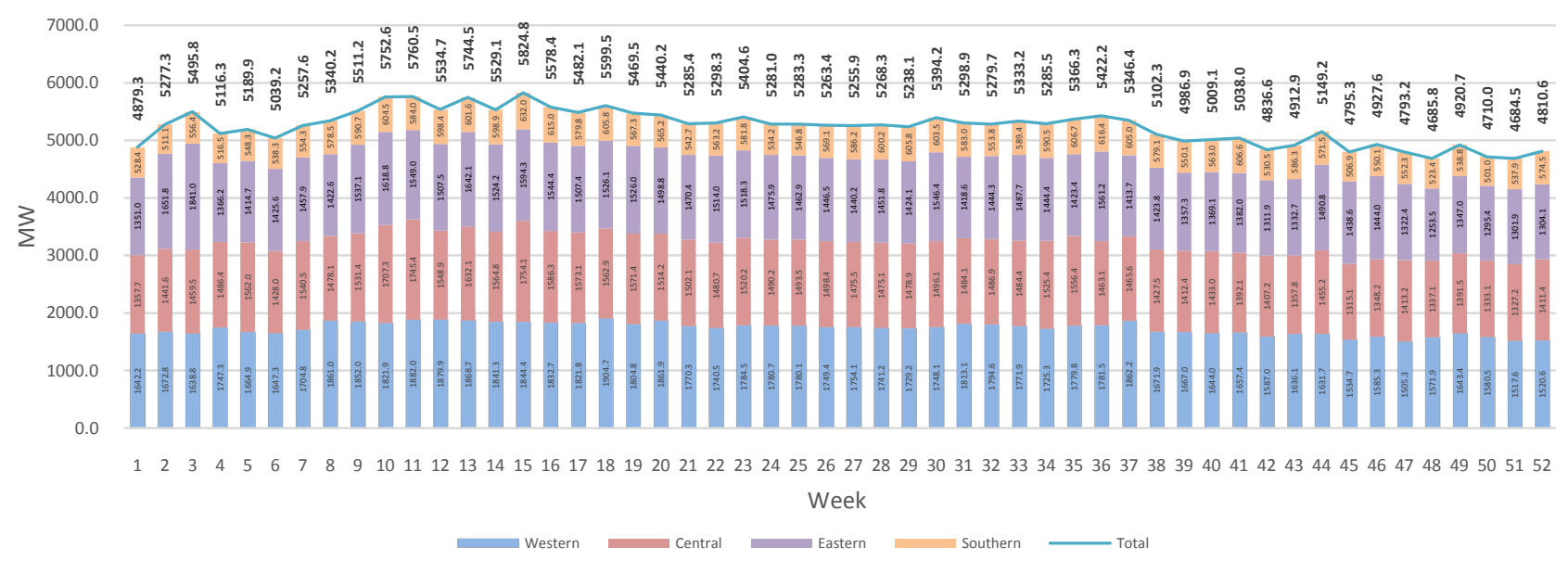

Figure 5. PV power.

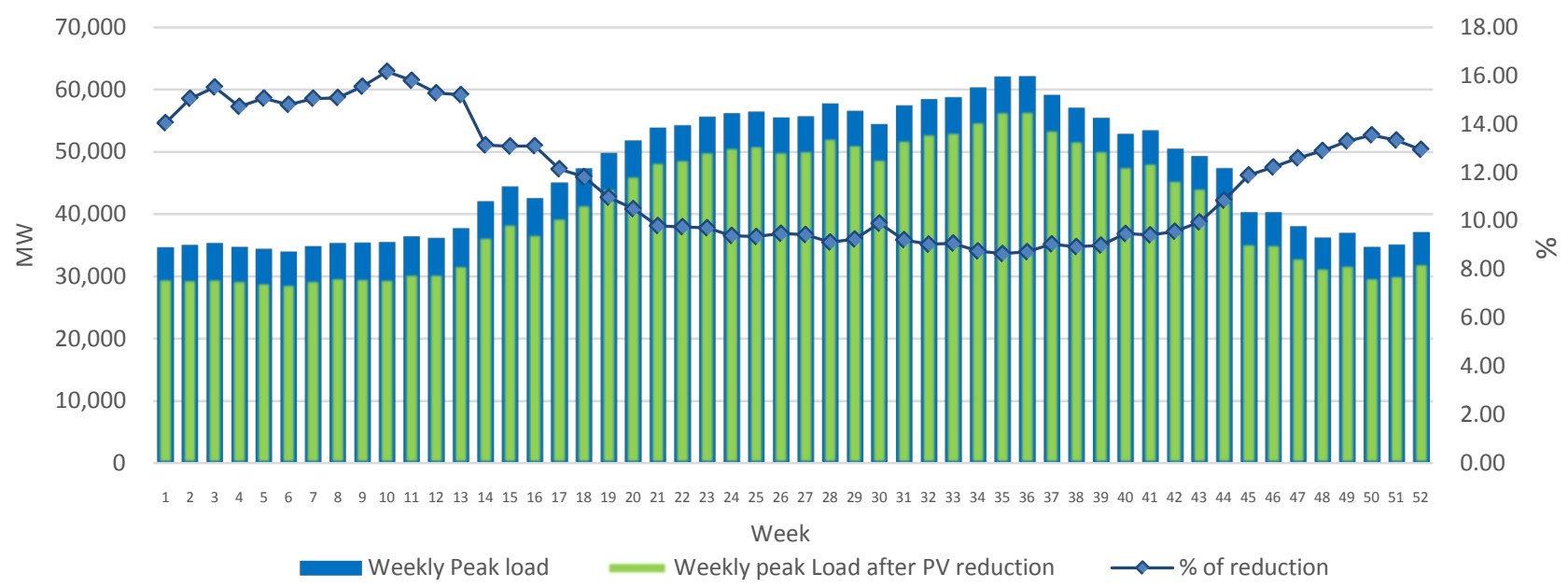

Figure 6. Weekly peak shaving.

of the paper. As a result, $61.31 \%$ of Saudi Arabia's 2030 target for renewable energy has been successfully attained. Hence a significant saving in fossil fuel has also been achieved since PV output power considerably shaved the weekly peak load with an average reduction of $11.73 \%$. The results show that the higher temperatures in the summer impacted the PV output power and the higher weekly 
peak shaving results always occurred during the winter.

\section{References}

[1] The Electricity \& Cogeneration Regulatory Authority (ECRA) (2017) Activities and Achievements of the Authority 2014.

http://www.ecra.gov.sa/en-us/MediaCenter/doclib2/Pages/SubCategoryList.aspx?cat egoryID $=4$

[2] Saudi Electricity Company (2017) Saudi Electricity Company Annual Report 2015. https://www.se.com.sa/en-us/Pages/AnnualReports.aspx

[3] King Abdullah City for Atomic and Renewable Energy (2017) Energy Sustainability for Future Generations. http://www.kacare.gov.sa/

[4] Saudi Electricity Company (2017) Electrical Data (2000-2014). https://www.se.com.sa/en-us/Pages/ElectricalData.aspx

[5] Ecra.gov.sa (2017) The Electricity \& Cogeneration Regulatory Authority. http://www.ecra.gov.sa/en-us/dataandstatistics/pages/DataAndStatistics.aspx

[6] Proctor Engineering Group Ltd., AMAD Technical Consultation and Laboratories (2017) High EER at $46^{\circ} \mathrm{C}$ Kingdom of Saudi Arabia Air Conditioner Project. https://www.proctoreng.com/dnld/I104EERFinalReportPEG012113.pdf

[7] Rahman, F., Rehman, S. and Abdul-Majeed, M.A. (2012) Overview of Energy Storage Systems for Storing Electricity from Renewable Energy Sources in Saudi Arabia. Renewable and Sustainable Energy Reviews, 16, 274-283.

https://doi.org/10.1016/j.rser.2011.07.153

[8] Saudi Vision 2030 (2017) Saudi Vision 2030. http://vision2030.gov.sa/sites/default/files/report/Saudi_Vision2030_EN_0.pdf

[9] Rehman, S., Bader, M.A. and Al-Moallem, S.A. (2007) Cost of Solar Energy Generated Using PV Panels. Renewable and Sustainable Energy Reviews, 11, 1843-1857. https://doi.org/10.1016/j.rser.2006.03.005

[10] NREL and KACST (2017) NASA Remote Sensing Validation Data: Saudi Arabia. http://rredc.nrel.gov/solar/new_data/Saudi_Arabia/

[11] Zell, E., Gasim, S., Wilcox, S., Katamoura, S., Stoffel, T., Shibli, H., Engel-Cox, J. and Al Subie, M. (2015) Assessment of Solar Radiation Resources in Saudi Arabia. Solar Energy, 119, 422-438. https://doi.org/10.1016/j.solener.2015.06.031

[12] Dubey, S., Sarvaiya, J.N. and Seshadri, B. (2013) Temperature Dependent Photovoltaic (PV) Efficiency and Its Effect on PV Production in the World-A Review. Energy Procedia, 33, 311-321. https://doi.org/10.1016/j.egypro.2013.05.072

[13] Abbes, D., Martinez, A. and Champenois, G. (2014) Life Cycle Cost, Embodied Energy and Loss of Power Supply Probability for the Optimal Design of Hybrid Power Systems. Mathematics and Computers in Simulation, 98, 46-62. https://doi.org/10.1016/j.matcom.2013.05.004

[14] Trina Solar (2017) Design a PV System with the Trina Solar TSM-250-PC/PA05A (250W). http://www.trinasolar.com/us/ 